\title{
Culture and Language Issues: From Blue Stocking to Manhole
}

\author{
By Roman Kritsberh ${ }^{*}$
}

\begin{abstract}
The language changes in history reflect our evolutional attitudes to complex of social issues. The interaction between language and culture may be both overt and covert and manifests itself in showing-up national, religious, gender, and other differences. The English language historically reveals strong bias against people of other nations, non-Christian believers, and women. Nowadays, there is a clash involved between the drive for political correctness and that for clarity of expression.
\end{abstract}

\section{Introduction}

The relations between language and extra-linguistic reality have always been both the cornerstone and stumbling block of interdisciplinary studies. Language determinism by antecedent external factors, loosely called "environment", "mileau", or "culture", has been taken for granted long ago. Language expresses, reflects, or identifies cultural differences in an encoded form that crystallizes past experiences of each and every nation. Custom, as B. Jonson put it with a wide implication, "is the most certaine Mistresse of Language, as the publicke stampe makes the current money" (Manley 1980: 193).

The interaction between language and environment may be both overt and covert manifesting itself not only in lexis but on other language levels. The drawl in the South of the USA, breaking, lengthening, and diphthongization of vowels, might be preconditioned by hot climate and a slow pace of life in the region. The signatures of the Scouse accent, the dialect of Liverpool, might be muffled within the sinuses, a feature some linguists attribute to the effect that coal burning had on the nasal passages during the city's industrial period.

The culture of Old Germans in some way "promoted" The First Consonant Shift (Grimm's Law), interrelated changes in the series of stops and fricatives from Proto-Indo-European to Proto-Germanic languages. What is the correspondence, if any, between the Kurgan burial of Proto-Indo-European along with the domestic horse and the chariot, ethnic markers of those (Mallory 1996: 183), on the one hand, and the system of ablaut, a characteristic feature of IndoEuropean - vocalic alternations accompanied by morphological changes, on the other?

In the modern German the process of "accusativation", the substitution of dative case as the one of direct object for accusative with near passive meaning is in full swing, e.g. instead of einem Waren liefern it is called einen mit Waren beliefern "to supply someone with goods". The resulting constructions, those with Direct Object, can easily be transformed into Passive Voice making the statements more impersonal. This trend has close connection to the circumstances of modern society, where the advance of passive constructions is seen as steady loss of

\footnotetext{
* Associate Professor, State Pedagogical University, Ukraine.
} 
personal "free space", and human beings are regarded as "cogs" of the system, just "tools" to maintain the "machinery" going (König 2001: 119).

\section{Literature Review}

E. Sapir considers language "a complex of symbols reflecting the whole physical and social background in which a group of men is placed...". The former includes geographical characteristics (the topography of the country, climate, etc.), along with the economic basis of the human life (fauna, flora, mineral resources of the region, etc.). Under the latter "are comprised the various forces of society that mold the life and thought of each individual", such as religion, ethical standards, form of political organization, and art (Sapir 1985: 90).

B. Whorf emphasizes the interaction between language and culture while writing of "unanimity of major patterns" in modern European languages, "but this unanimity exists only because these tongues are all Indo-European dialects cut to the same basic plan, being historically transmitted from what was long ago one speech community; because the modern dialects have long shared in building up a common culture" (Whorf 1967: 214).

It is known that language is never about the language per se, but about political and cultural influence, immigration, economy, etc. As W. Wolfram puts it; "We make judgments about regional backgrounds, social status, ethnicity, and a host of other social characteristics based simply on the kind of language people are using" (Wolfram 1998: 1). If the "strong version" of the E. Sapir and B. Whorf's theory, that language determines the way people think, may sound controversial, the "weaker version", that language differences affect our perception, is quite acceptable (Crystal 2000: 15).

\section{Methodology}

The present paper brings to light the dynamics of the language changes in history which reflect our shifting attitudes to racial, religious, gender, and other social issues. The corresponding lexical items and textual sources, both historical works of G. Chaucer and W. Shakespeare, and contemporary - British and American newspapers, serve as material for the paper. The methodology includes methods of descriptive analysis, and that of discourse analysis.

\section{Findings - Discussion}

Firstly, the national bias is important for consideration. Stereotypes of thinking, especially the bias against people of nations other than one's own, have always been present in any language. Thus, the word barbarian with an etymological meaning "a foreigner, whose language and customs differ from the native inhabitants" has multiple applications revolving around the basic concept. 
In Old Greece, it was used for "one who is non-Hellenic", in the Roman Empire, it referred to one "who lives outside its borders and civilization", especially to the northern neighbors, Germans. Then, as Christian civilization had taken over, it was applied to an alien outside its domain. In the Italy of the Renaissance, it meant "one of a nation outside Italy". Chinese used to employ the word to foreigners, as well. In Hebrew the word goy with original sense "nation, people (other than Jewish)" now "Gentile", "not-religious Jew", has a heavy connotative opprobrium. The presumable history of the word bizarre may be connected with the Basque word bizarra "beard" which gave the sense in Spanish "a man of spirit, choleric" with the negative connotation referring to the Basque people as to their character and appearance. Among other versions, bigot, came from the custom of German soldiers with military moustache in Spain, considered as aliens, to say "Bei Gott!" ("by God!"), then in the $16^{\text {th }}$ century the word had the sense "with moustache" and later through French acquired the meaning "too pious, hypocrite" (Kluge 1975: 76).

The English language is no exception and bears the same ugly marks of cultural intolerance and negative connotation towards people of other nations. Thus, the expressions with the first item Dutch reflect a bitter, long-standing struggle and rivalry between two nations for the dominion both in the Old and New Worlds, especially in the $17^{\text {th }}$ century. Apparently, since that time the Dutch acquired, according to OED, "opprobrious or derisive application ... often with allusion to drinking habits ascribed to 'the Dutch' ... to their broad heavy figure" (Simpson and Weiner 1994: 487) "Dutch" had become in English a synonym for "foreigner", "non-English", "something untrue, ridiculous, weird" as in Dutch auction, bargain, comfort, lunch, party, treat, feast, treat, act, uncle, to go Dutch, I am a Dutchman, etc. The same tendency goes well in American English (AE), as in Dutch "dander, anger", to get in Dutch "to get in favor or disgrace", to take Dutch leave "to leave military organization without permission", to beat the Dutch "to overcome something difficult or surprising". Through all political correctness, connotation of Dutch has little but changed in modern English, as in Dutch cap "contraceptive diaphragm", Dutch bath "a sponge bath, one requiring a minimum of water", Dutch nickel "a stolen kiss", etc.

A long-lasting face-off between the English and Native Americans in the New World brought about negative connotation associated with the latter, as in the following lexical items: Indian hay "marijuana", Indian giver "one who gives something to another and then takes it back", Indian gift "such gift", Indian wrestling, Indian "temper, dander".

The French have not been treated more hospitably by the English culture and language than others. Such lexical items as French harp "harmonica", French leave "sudden, impolite and abnormal departure", to speak French "to practice oral sex", French "pornographic, improper", as excuse my French, French cap, French letter "condom", French furlough "a case of desertion from army", French hospitality "minimal hospitality or no hospitality at all", Frenching "a tobacco \& cotton plant disease characterized by the thickening, curling and narrowing of leaves", etc. bear indelible signs of contempt and disparagement. Many other 
combinations where the first element French indicates the origin of the things can hardly sweeten the deal.

The list of English disparaging designation for people of nations and races other than Anglo-American along with association of those is black enough to be thoroughly read through: Chink "a person of Chinese descent", Chinaman's chance "an extremely poor chance", frog "French person", wop "Italian", Dago "a person of Latino origin", Kraut, Heinie, Fritz "German", square-head "a German, Dutchman, or Scandinavian", greaser "a Mexican", kike "Jewish", to scotch "to put an abrupt end to", to welsh "to cheat a person out of money, failure to fulfill ones promise", bohunk "a person from east-central Europe", to name only but a few.

Strong racial intolerance to nations and races other than the Anglo-Saxon was the hallmark of the English culture and language in early Modern English. The works of $\mathrm{W}$. Shakespeare reflect this strong racial bias, as:

"Launce ... yet did not this cruel-hearted cur shed one tear. He is a stone, a very pebble stone, and has no pity in him than a dog: a Jew would have wept to have seen our parting" [The Two Gentlemen of Verona: II.iii.29-33].

"If thou wilt go with me to the alehouse so; if not, thou art a Hebrew, a Jew, and not worth the name of a Christian" [Ibid: II.v.56-9].

Hungarian in early Modern English was slang word for "thievish, marauding, beggarly, poor" and "hungry", it is base in The Merry Wives of Windsor [I.ii.21-7], along with base Phrygian Turk [Ibid: I.ii.94-5]. Turks are also cruel and savage, as "... if the rest of my fortunes turn Turk with me, with two Provincial roses on my razed shoes, get me a fellowship in a cry of players" [The Comedy of Errors: III.ii.291-4]. Here, the expression to turn Turk implies the cruelty and savagery of the Turkish people associated with the merciless fortune. Bohemian and Tartar bear also the general sense of opprobrium. Although OED states that the sense "adventurer, vagabond" of the former was introduced in English by W. Thackeray (Simpson and Weiner 1994: 154), its usage along with Tartar ("vagabond, beggar, thief") speaks for its much earlier origin: "Host. Here's a Bohemian-Tartar tarries the coming down of thy fat woman" [The Merry Wives of Windsor: IV.v.21-22]. "No, he's in Tartar limbo, worse than hell" [The Comedy of Errors: IV.ii.32].

In Macbeth, "Liver of blaspheming Jew, ... Nose of Turk, and Tartar's lips ... Make the gruel thick and slab" [IV.i.26.29.32]. Chinese in Early Modern English, are "sharpers, con-men" from the supposed skillful thieving of those people and "scoundrel": "I will not believe such a Cataian [=Chinese], though the priest o' the town commended him for a true man" [The Merry Wives of Windsor: II.i.147-9]. 
European nations other than English also fare very low in W. Shakespeare's works: "I will rather trust a Fleming with my butter, Parson Hugh the Welshman with my cheese, an Irishman with my aqua-vitae bottle, or a thief to walk my ambling gelding than my wife with herself" [Ibid: II.ii.320-4]. Or the famous dialog in The Comedy of Errors [III.ii.117-144], where Dromio of Syracuse speaks of his fat mistress by comparing her body to the globe, which contains a lot of derogatory remarks of different countries: "... she is spherical like a globe; I could find out countries in her" - Ant. S. "In what part of her body stands Ireland?" - Dro. S. "Mary, sir, in her buttocks: I found it out by the bogs" - Ant. S. "Where Scotland?" - Dro. S. "I found it by the barrenness; hard in the palm of the hand" - Ant. S. "Where France?" Dro. S. "In her forehead; armed and reverted, making war against her heir" ... Ant. S. "Where stood Belgia, the Netherlands?" - Dro. S. "O, sir! I did not look so low".

Russians, French, and Polish are no more fortunate, as: "Angelo. This will last out a night in Russia, When nights are longest there" [Measure for Measure: II.i.144-5]. "Knock, knock, knock! Who's there? Faith, here's an English tailor come hither for stealing out of a French hose" [Macbeth: II.ii.15-16]. "So frown'd he once, when in an angry parle, He smote the sledded Polacks on the ice" [Hamlet: I.i.62-63].

Those examples show the clear-cut language bias against national minorities, brought about by the worldview of corresponding times.

Religious intolerance has been also clearly expressed in the language. Thus in the Middle Ages the word maumetry meant "false religion, heathenism, idolatry" (maumet "false god, idol") from erroneous notion that Prophet Muhammad was worshiped as god, and negative connotation with Islam. The word macabre with positive evaluation in the Jewish culture and Hebrew language (Maccabee "epithet for Jewish patriot Judas Maccabæus", generally "his supporter, followers, martyrs, fighters for peace" after recorded the Jewish revolt against Antiochus IV) was shifted in French, English, and other European languages, as in danse Macabre "dance of death" and then to macabre with hostile connotation "suggesting the horror of death, gruesome", along with the blunt meaning "referring to a corpse, human remnants". Another example of that kind is Sabbath. Originally, a Jewish holy day of rest, Saturday, has shifted its application to "a night meeting demons, witches and other evil forces presided over by the Devil" in most of European languages mainly because of prejudice against the Jewish culture.

In its turn, the word assassin established in many European languages and containing negative evaluation came from Arab hashishīyyin plural of "hashisheater" with matter-of-fact designation which was used about some Muslim fanatics who in the time of the Crusades intoxicated themselves with drugs to murder Christian invaders.

A lot of examples of religious intolerance towards beliefs other than Christian are found in G. Chaucer's works, as: "I seye, by tretys and embassadrie, and by the popes mediacioun, and al the chirche, and al the chivalrie, That in 
destruccioun of mawmettrie, and in encrees of Cristes lawe deere" [The Man of Law's Tale: 233-7]. - "I say, by treaties and negotiations, and by the Pope's mediation, and all the church and nobility That in elimination of idolatry, and in promotion of Christ's dear law". ${ }^{1}$ Another example is: "This ilke worthy knyght hadde been also Somtyme with the lord of Palatye Agayn another hethen in Turkye" [General Prologue: 64-66]. - "The same worthy knight had once also been [in campaign] With the lord of Palatia Against another heathen people in Turkey".

Bugger as term of abuse originally was applied to the sect of Albigenses or Cathar, who practiced their belief, based on ascetic renunciation of the world in the southern France in $12^{\text {th }}$ and $13^{\text {th }}$ centuries and were persecuted by the Inquisition. The word later was applied to other heretics, as well as to whom the pervert practice was ascribed. The origin of this word, along with the earlier bougre is Bulgaria, although the Bulgarian origin of the sect is disputed.

Even within Christian religion non-orthodox sects were branded as mavericks, and the stigma attached to them is reflected in the language. Thus, libertines originally were antinomian sects that arose in the early $16^{\text {th }}$ century in Europe and their followers confessed the priority of the "law of grace" over binding Christian moral (Simpson and Weiner 1994: 967). Later, the word libertine developed negative connotation as "one of loose moral and irresponsible behavior", e.g.: "Why, he is a prince's jester: a very dull fool; only his gift is in devising impossible slanders: None but libertines delight in him" [Much Ado About Nothing: II.i.144-146]. "Show me the steep and thorny way to heaven, Whiles, like a puff'd and reckless libertine, Himself the primrose path of dalliance treads" [Hamlet: I.iii.48-50].

Another case in point is gender bias in language in the male-dominated world, so far. A lot of derogatory lexemes originally applied to men gradually crept over the line to be referred exclusively to women, e.g. the phrase Blue Stocking was originally applied to gentlemen only, intellectual parties, later transferred to educated women with negative implication. Or coquette, diminutive of coq "cock", originally referred to male lover or womanizer, then used of both sexes, now spares men from this sense of vanity and its strings attached.

The word harlot as well used to designate a worthless male, good-for-nothing, base fellow, villain as early as in the $13^{\text {th }}$ century. Then the connotation was softened as "a man of loose moral", "juggler, trickster" giving way to positive sense "good man, charming rascal". G. Chaucer uses the word mostly referring to males in various senses: "He was a gentil harlot and a kind; A better felawe sholde men noght fynde" [Prologue: 647-8]. - "He was a gentle and kind fellow; You would not find a better one". "For thogh this Somonour wood was as an hare, To tell his harlotrye I wol not spare" [The Friar's Tale: 1327-8]. - "Although this summoner was as mad as hare, I would not spare telling about his villainy". "Ye, false harlot, quod the millere, hast? A, false traitour, false clerk! quod he, Thow shalt be deed, by Goddes dignitee!" [The Reeve's Tale: 4268-70]. - "'You, false rogue', said the miller, have you [slept with my daughter]? Hey, false traitor, false scholar! said he, You should die, by God's name!". "The Reve answered and seyde, Stynt thy clappe! Lat be thy lewed drunken harlotry It is a synne and eek a

\footnotetext{
${ }^{1}$ G. Chaucer's examples are translated into Modern English by the author of the paper.
} 
greet folye To apeyren any man or hym defame ..." [The Miller's Tale: 3144-7]. "The Reeve answered and said, Shut your row! Have done with your stupid drunken ribaldry It is a sin and also great foolishness To put a blame on a man or defame him ...". "A sturdy harlot wente ay hem bihynde, That was hir hostes man, and bar a sak, And what men yaf hem, layde it on his bak" [The Summoner's Tale: 1754-6]. - "A sturdy fellow always went behind them, He was a servant to the guests at the friar's convent and carried a sack, and put on his back whatever people gave them".

Later, from the $15^{\text {th }}$ century on, the opprobrious sense was finally passed to females only, although W. Shakespeare still uses it frequently in the old sense: "This day, great duke, she shut the doors upon me, While she with harlots feasted in my house" [The Comedy of Errors: V.i.204-5].

The story repeats itself in the word shrew: originally "a wicked, malignant, evil-disposed man, rascal", then it applied to the Devil, later referred to people of either sex to end up on "malignant, peevish and perverse woman, wife". G. Chaucer uses the word in the first sense: "Lo Grenewych, ther many a shrewe is inne! It were al tyme thy tale to bigynne" [The Reeve's Prologue: 3907-8]. "There is Greenwich, where many rascals live.; It's just a time to begin your tale". "Irous Cambises was eek dronkelewe, And ay delited hym to been a shrewe" [The Summoner's Tale: 2043-4]. - "Wrathful Cambyses was also a drunkard, and always took delight in being rascal".

A similar development is observed in the words bawd and brothel. The former as "pander, go-between, procurer in sexual debauchery", according to OED (Simpson and Weiner 1994: 113), in most cases originally had been masculine, but since 1700 is used about women-keeper of a brothel. Both G. Chaucer and W. Shakespeare use it in an old sense: "Thus false theef, the somonour, quod the Frere, Hadde alwey bawdes redy hond, As any hauk to lure in Engelond ..." [The Friar's Tale: 1338-40] - "Thus this false thief, the summoner, the Friar said, Had always a lot of panders, Whom he could easily lure to his hand, as any hawk in England". "He was, if I shal yeven hym his laude, A theef, and eek a somnour, and a baude. He hadde eek wenches at his retenue" [Ibid: 1353-5]. - "He was, if I shall praise him, A thief, and also a summoner, and a pimp; He had also young maids at his service". "He, sir! a tapster, sir; parcel-bawd; one that serves a bad woman" [Measure for Measure: II.i.64-5].

The word brothel in the $14^{\text {th }}$ century stood for "a worthless fellow, good-fornothing", then from the $15^{\text {th }}$ century on, took it out on women with the sense "prostitute, whore" to substitute for the earlier bordel as "a house of prostitution", beginning with the $16^{\text {th }}$ century.

Although another word whore, with the kindred Hure in German refers to women, its etymology and related words clearly show its original male application: Gothic hors "adulterer, marriage-breaker", Latin cārus "dear", Old Irish cara "friend", Lettish kārs "lascivious" (all masculine gender) (Kluge 1975: 322). It is worth mentioning here that German Dirne "prostitute" etymologically goes back to Common Germanic feminine *Dewerno "wench, maid", which is derivative from masculine Pegnas "fellow", with the former in and the latter out of use in modern German. Another word callet "a lewd woman, prostitute" marked 
by OED "obsolete except dialect" was current from the $15^{\text {th }}$ through the $18^{\text {th }}$ centuries. Although its origin is disputed, one of the possible sources according to OED (Simpson and Weiner 1994: 202) is French caillette "fool", "general term of abuse" which originally was applied both to men and women. However later opprobrious designation was restricted to females.

The word gossip with contemporary negative evaluation originally had positive one - "one who has spiritual affinity with another, acting as a sponsor at baptism: a godfather or a godmother", later developing into "a friend of both sexes". The turning point took place in the $14^{\text {th }}$ century, when the word acquired a new sense "a female acquaintance, friend" that drastically changed it connotation to "a woman-tattler, gossipmonger". G. Chaucer's and W. Shakespeare's usage still shows its neutral meaning: "He som tyme was a clerk at Oxenford, And hadde left scole, and wente at hom to bord With my gossib dwellyne in oure toun; God have hir soule! Hir name was Alisoun. She knew myn herte, and eek my privetee" [The Wife of Bath's Prologue: 527-31]. - "Once he was a scholar in Oxford, and he left school and went to board at home with my female friend dwelling in our town; God bless her soul! Her name was Alison. She knew my heart and also my secrets. Go to the gossip's feast and joy with me: After so long grief such festivity" [The Comedy of Errors: V.i.408-9].

G. Chaucer shows a lot of abusive language towards women in his The Canterbury Tales: "'Brother', quod he, heere woneth an old rebekke, That hadde almoost as lief to lese hire nekke As for to yeve a peny of hir good" [The Friar's Tale: 1573-5]. - "'Brother', he said, here lives the old hag, who would rather lose her head than give a penny of her goods". "This somonour clappeth at the widow's gate. 'Com out', quod he, 'thou olde virytrate! I trow thou hast som frere or preest with thee"' [Ibid: 1581-3]. - "This summoner knocked on the widow's gate. 'Come out', he said, 'you old hag! I think you have some friar or priest with you"'. "'Nay old stot, that is nat myn entente,' Quod this somonour, for to repente me For any thyng that I have had of thee" [Ibid: 1630-2]. - "'No, old hag, this is not my intention,' Said this summoner, to feel sorry About anything that I have had from you". "And so bifel that ones on a day That somnour, evere waityng on his pray, Rood for to somne an old ribibe ..." [Ibid: 1575-7]. - "And it happened that one day This summoner, always waiting for his prey, Rode to some old woman".

W. Shakespeare follows this lead: "Out of my door, you witch, you rag, you baggage, you polecat, you ronyon!" [The Merry Wives of Winsdor: IV.ii.197-9]. Here: baggage, rag, polecat, runnion - all terms of female abuse. "Lucio. My lord, she may be a punk; for many of them are neither maid, widow, or wife" [Measure for Measure: V.i.175-6]. Here: punk - obsolete for "prostitute".

Although the word wretch "a mean, despicable person" was very common since 1300, in W. Shakespeare's plays it refers chiefly to women: "Duke. By heaven, fond wretch! Thou know'st not what thou speak'st" [Ibid: 106].

The other examples that follow also reveal clear-cut gender bias in Early Modern English. Thus, in the $15^{\text {th }}$ and $16^{\text {th }}$ centuries, the word concubine was applied both to female and male paramours, but then the latter sense became obsolete. Although villain as "a person with bad qualities" refers mainly to men, starting in the $16^{\text {th }}$ century, it has been also applied to women: "Din'd at home! 
Thou villain, what say'st thou?" [The Comedy of Errors: IV.iv.69]. Another example of the same kind is giglot. In the Middle-Early Modern English, it was applied to the members of both sexes: "of a man: merry-maker" (obsolete) and "lewd, wanton woman" (obsolete). Only the latter is used now with less emphatic connotation "a giddy, romping girl". The male-related senses came into disuse: "Away with him to prison! Lay bolts enough on him, let him speak no more. Away with those giglots too, and with the other confederate companion!" [Measure for Measure: V.i. 345-7].

One more set of examples of similar language discrimination against women that reflects social inequality is given by R. Lakoff (Lakoff 1973). Through apparent parallelism in terms of relationship the author shows "the linguistic double standard" that holds in applying to men and women. Thus in the pair master: mistress the former has positive evaluation referring to man's distinguishing features, accomplishments in some field or power to exercise over others, while its feminine counterpart mainly implies "a sweetheart, lady-love". " $A$ man is defined by what he does; a woman by her sexuality ... in terms of ... her relationship to men" [Ibid]. We can add to this the pair dominus "lord, master" versus dame. The former kept its high status, as in obsolete domine of the same sense along with the derivatives dominion, dominium, while the latter originally meant "female ruler, superior or head, lady", along with a form of address to a woman of rank or woman of position, gradually descended to "mistress of the house, housewife", "old housewife", "a mother of human beings and animals", and just "woman, girl" used disparagingly in American slang. That change is already reflected in G. Chaucer's works: "That Jankyn clerk, and my gossyb dame Alys, And I myself, into the feeldes wente" [The Wife of Bath's Prologue: 548]. - "That scholar Jankin and my friend housewife Alis and I went in the fields". "I bar hym on honde he hadde enchanted me, - My dame taughte me that soutiltee" [Ibid: 5767]. - "I assured him that he had enchanted me, - My mother taught me that trick". It is worth mentioning that the word dam, variant of the dame, is used disparagingly, as the devil's dam "woman", e.g.: "Dro. S. Nay, she is worse, she's the devil's dam, and here she comes in the habit of a light wench" [The Comedy of Errors: IV.iii.50-1].

Deterioration of the senses related to women is also a case in point of gender bias. Thus, the word beldam originally had indirect connection to the French belle dame "fair lady", then it acquired now obsolete sense "a grandmother", turning consecutively to "an aged woman, a matron of advanced years, especially in addressing nurses in the $16^{\text {th }}$ century", ending with depreciative meaning "an old hag, an loathsome old woman" (Simpson and Weiner 1994: 123), as in following: "First Witch. Why, how you, Hecate! Hec. Have I not reason, beldams as you are, saucy and overbold?" [Macbeth: III.v.1-3].

The more ancient word wife before being replaced by Middle English woman, which was not current in the earliest period of Old English (wif + mon "female human being"), had the meaning of the latter and then narrowed this sense to that of "woman of low standing", "one who sells some commodity", now as fish-wife, ale-wife, etc. This pejoration did not take root in G. Chaucer's time. The writer uses wife both in a good and bad connotation: "No creature saugh he that bare lyf, 
Save on the grene he saugh syttinge a wyf - A fouler wight ther may no man devyse" [The Wife of Bath's Tale: 997-9]. "He saw no living creature Apart that he saw a woman sitting on the grass - No one could imagine the uglier creature". "Ful many a noble wyf, and many a mayde, And many a wydwe, for that they been wise, The queene hirself sittynge as a justice" [Ibid: 1026-8]. "There were many noble women, and many maids, And many widows because they were wise, the queen herself sitting as the judge".

Similar pejoration took place in the word quean (counterpart of queen): originally "a wife, female", from early Middle English on, it turned into a term of abuse ("impudent, ill-behaved woman") and in the $16^{\text {th }}-17^{\text {th }}$ centuries - to "harlot, prostitute". E.g.: "A witch, a quean, an old cozening quean! Have I not forbid her my house?" [The Merry Wives of Winsdor: IV.ii.184-5].

In the following examples positive evaluative senses referring to women were shadowed and substituted by those applying to men. Fellow in an old meaning "one who associates with others, companion, partner" from the beginning of the $14^{\text {th }}$ century through the middle of the $17^{\text {th }}$ century was used of women as well before giving up its ground to association with males in all its senses, as in the following quotation from W. Shakespeare: "I am your wife, if you will marry me; If not, I'll die your maid: to be your fellow You may deny me; But I'll be your servant Whether you will or no" [Tempest: III.i.82-86]. Bully as a term of endearment had been originally applied to both sexes, then with implication of friendly admiration ("swell fellow") was restricted to men only. The negative sense "intimidator" developed much later. The word child in Middle and Early Modern English was used of a girl not a boy. W. Shakespeare uses it only this way: "Mercy on's, a barne; a very pretty barne! A boy or a child, I wonder? A pretty one" [The Winter's Tale: III, iii, 70-72].

The word wench with the modern senses "a wanton woman", "a young rustic girl" and "a char-woman" that bear clear-cut detracting connotation originally referred to just young woman, female child. Etymologically, it goes back to the obsolete one wenchel "a child of either sex". As the latter acquired unflattering notions of those "servant, slave" and "common woman", the semes of male gender disappeared. G. Chaucer uses wench almost exclusively as "wanton woman": "He hadde eek wenches at his retenue ..." [The Friar's Tale: 1355]. "He had also loose women at his disposal ...". "... Thus was the wenche and he of oon assent ..." [Ibid: 1359]. "And that loose woman and he were at one ...". And pile the man, and lete the wenche go. Thanne wolde he seye, "Freend, I shal for thy sake Do striken hire out of oure lettres blake; Thee thar namoore as in this cas travaille" [Ibid: 1362-5]. "And [he] accused (robbed) the man and let the loose woman go. Then he would say, Friend, I have stricken her out of Our black books for your sake, You needn't trouble yourself any more about it".

Rise of political correctness in the USA in the $19^{\text {th }}$ century. By our estimates, the changing tide in the English language is referred to the beginning of the $19^{\text {th }}$ century in America. British travelers witnessed the nascent political correctness there. Thus, J. Davis wrote: "Every public-house in the United States, however contemptible, is dignified by the name of Tavern" (Davis 1803: 32). F. Cuming 
recorded the abundance of the word handsome, as handsome square roofed house, handsome appearance (of the city): "Portsmouth is in a handsome and healthy situation"; "handsome bird's eye view of that town"; "handsome grove", "handsome fortune" (Cuming 1905: 108, 161, 234, 250, 324). Grocery store in early American English meant "a licensed one, selling alcoholic drinks". F. Trollope noted "[men] of high standing", "lady of high standing", "young lady (=chambermaid)", and was amused by the word help "servant" (Trollope 1832: 61, 83, 119, 161). T. Hamilton mocked American phrases: "in possession of the floor (=to take the floor)", "a great improvement", as "On the morning we came to Portland, a wretched settlement, consisting of a store and a few wretched houses". This is what is called, in American phrase, "a great improvement", "a considerable place" (Hamilton 1834: 3, 83, 249, 252).

F. Marryat related the episode when he inquired about the young lady's leg grazed by the fall. The lady was shocked and said that limb would have been a proper word (Marryat 1840: 18). T. Grattan was scathing about political correctness in the USA: "... filagree phrase and silken term precise of attempted and affected fine speaking", he sees here "underbred affectation ... ordinary minds are always afraid of homely words". Among the author's examples are garments for "clothes", mansion for "house", vehicle for "carriage", domestics for "servants", the atmosphere for "the air", where did you worship? for "what church were you at?", I opine for "I think", an incorrigible inebriate for "drunken fellow", corsets for "stays", elastics for "garters", hose for "stockings", limbs for "legs", white meat for "chicken breast", dark meat for "poultry legs", rooster for "cock", helps for "servants" (Grattam 1859: 55).

I. Bird also mentions PC. The author very seldom heard profanities, which grated on her ear in England. Especially such language was banned before ladies. In general, what struck her the most was the extreme respect and deference of Americans in their manners to ladies. Once, she witnessed as a gentleman gave up his seat in a stage coach to a young girl and had to stay at the roadside inn for a day and two nights, the episode taken for granted by the fellow-travelers. On another occasion, an author's friend on leaving a hotel offered a tip of half a dollar to a servant, but "she drew herself up and proudly replied, 'American ladies do not receive money from gentlemen"' (Bird 1856: 78). In England, it would be difficult for the author to travel by railroad unattended, but in the USA, she went several thousand miles on her own.

Max O'Rell mocks some modes of speech: "The employees (I must be careful not to say 'servants') of the Pennsylvania Railroad", "The cold, icy air fell on my legs, or (to use a more proper expression, as I am writing in Philadelphia) on my lower limbs", "At eleven o'clock I went to bed, or, to use a more proper expression for my Philadelphia readers, I retired" (O'Rell 1891: 83, 266, 300).

The criticisms of the officialese, weasel-words, goes back to 1914 when S. Graham gives an example of President Wilson's speech: "So far as the prognosticationary and symptomatic problem-aciousness of your inquiry is concerned it appears to me That while the trusts should be regulated with the most unrelentful and absquatulatory rigorosity, yet on the other hand their feelings 
should not be lacerated by rambunktions and obfusticationary harshness" (Graham 1914: 250).

Changes in the language expression in the $20^{\text {th }}$ century. The $20^{\text {th }}$ century witnesses both the growing awareness of society the way it talks about itself along with the backlash against political correctness, which became "the most pernicious form of intolerance", "a lethal weapon for silencing anyone whose ideas you don't like" (Crystal 1995: 177). G. Orwell writes about such manipulation in 1946: "In our time, political speech and writing are largely the defense of the indefensible. Things like the continuance of British rule in India, the Russian purges and deportations, the dropping of the atom bombs on Japan, can indeed be defended, but only by arguments which are too brutal for most people to face, and which do not square with the professed aims of the political parties. Thus political language has to consist largely of euphemism, question-begging and sheer cloudy vagueness. Defenseless villages are bombarded from the air ...: this is called pacification. Millions of peasants are robbed of their farms and sent trudging along the roads with no more than they can carry: this is called transfer of population or rectification of frontiers. People are imprisoned for years without trial, or shot in the back of the neck or sent to die of scurvy in Arctic lumber camps: this is called elimination of unreliable elements. Such phraseology is needed if one wants to name things without calling up mental pictures of them ${ }^{\prime \prime 2}$

Present-day trend. Some spheres where the drive to purify language of loaded words in the $21^{\text {th }}$ century clashes with clarity and transparency may be illustrated, as follows. In the office jargon there are some "offenders", as synergy, I'm thinking in real time, to execute, let's take this offline, going forward, let's action that, to empower, take it to the next level ("Can you take it to the next level and report back?"), to circle-back ("I'm just heading to a really important meeting but we will circle-back later"), we're on a journey ("This organisation is on a journey to a new beginning"), root-and-branch review ("We are undertaking a root-andbranch review of our sales team to identify hits and misses"), staff engagement, to reach out, work flows ("You all need to improve your work flows"), intrepreneurs (an entrepreneur who works for a large corporate), to leverage ("Let's see if we can leverage these options and drill down to the next level"), inside the box ("I actually think we need to think inside the box on this one"), conscious uncoupling ("You're fired"). ${ }^{3}$

In Great Britain, there is an attempt to scrap the traditional teachers' titles "Sir" and "Miss" because they discriminate against women. The Maryland State motto "Fatti maschii, parole femine" translated from Italian as "manly deeds, womanly words" is misogynist and sexist, as many experts think. Others insist that the correct idea is "strong deeds, gently words" or "action speak louder than words". ${ }^{4}$ Moreover, the state song of Maryland calls Abraham Lincoln a "despot" and "tyrant" ("The despot's heel is on thy shore ... Dear Mother, burst the tyrant's

\footnotetext{
${ }^{2}$ G. Orwell (1946) Politics and the English language. Retrieved from goo.gl/bcGkx.

${ }^{3}$ L. Peacock (2014, May 15) So, office jargon: the 19 worst offenders in management speak. Daily Telegraph. Retrieved from goo.gl/ueP1az.

${ }^{4}$ A. Shugar (2014, March 28) The Maryland motto is sexist in any language. The Washington Post. Retrieved from goo.gl/I2ZIIN.
} 
chain"), and the Union forces "Northern scum" ("Huzza! She spurns the Northern scum").

On college campuses of the USA, the growing number of students and faculty are challenging the English gender-related names, as agender, bigender, or unfamiliar gender pronouns ze, sie, $e, \mathrm{ou}$, and ve, as in the University of Vermont, the University of California. At Mills College students are now called "first-years" instead of "fresh women". 5

British Royal Navy has dropped its traditional sailors' toast to "our wives and sweethearts", followed often by "May they never meet!", now they drink to "their families". About half of all US states have moved toward such gender-neutral language at varying levels, from drafting bills to changing state constitutions, according to the National Conference of State Legislatures. Florida and Minnesota have already completely revised their laws, and Washington is following the lead. Although such words as manhole and manlock cannot be changed so easily. ${ }^{6}$

Another problem is the prejudice against red-haired people. The New Statesman reports about a number of assaults and even murders of red-haired people. Only a ginger can call another ginger ginger. Some experts go as far to explain the UK's uniquely aggressive gingerism as "a form of racism, rooted in anti-Celtic, specifically anti-Irish, prejudice and therefore related to centuries-old matters of imperialism, religious bigotry and war".7

Left-handed people are also stigmatized in language, as southpaw, cackhanded. In Britain, such derogatory names include buck-fisted, cow-pawed, corky dobber, dolly-pawed, gibble-fisted, golly-handed, keggy, squiffy, and scoochy. Experts are at loss, as well, about the way of calling the people who have advanced beyond the middle of their lives: senior, boomers, elderly, older people, older adults. People can be called terrorists and freedom fighters, rioters and protesters, desperate and open-minded, heavy-drinking and thirsty depending on our attitude. ${ }^{8}$

\section{Conclusions}

Language is marching in lockstep with social issues, being influenced by the cultural development of society, and in its turn, helps change our stereotypes. The English language has shown clear-cut historical bias against nations other than Anglo-Saxon, religious intolerance towards beliefs other than Christian, and gender discrimination against women. Other minorities suffer from abusive connotation. The state of things is in flux, at present. The historical tradition, which reflects the world-view of the past, with all its prejudices and

\footnotetext{
5 L. Leff (2013, December 01) "Preferred" pronouns gain traction at US colleges. The Huffington Post. Retrieved from goo.gl/KeXzJj.

${ }^{6}$ A. Shugar (2014, March 28) The Maryland motto is sexist in any language. The Washington Post. Retrieved from goo.gl/I2ZIIN.

7 A. Fogg (2013, January 15) Gingerism is real, but not all prejudices are equal to one another. The Guardian. Retrieved from goo.gl/kUtkQE.

${ }^{8}$ G. Nunn (2013, January 24) Clumsy and cack-handed? Lefties are leaders, not losers. The Guardian. Retrieved from goo.gl/LDgSrl.
} 
stereotypes, clashes with the political correctness, and the latter, in its turn, often affects matter-of-fact designation and clarity of expression.

\section{References}

Bird I (1856) The Englishwoman in America. London: Murray.

Crystal D (2000) The Cambridge Encyclopedia of Language. Cambridge University Press, 2000.

Crystal D (1995) The Cambridge Encyclopedia of the English Language. Cambridge University Press.

Cuming F (1905) Cuming's Tour to the Western Country (1807-1809). Cleveland: Clark Co.

Davis J (1803) Travels of Four Years and a Half in the United States of America: during 1798, 1799, 1800, 1801, and 1802. London.

Graham S (1914) With Poor Immigrants to America. New York: Macmillan.

Grattam T (1859) Civilized America. London: Bradbury.

Hamilton T (1834) Men and Manners in America. Edinburgh: Blackwood.

Kluge F (1975) Etzmologisches Wörterbuch der Deutschen Sprache (Etzmological dictionary of the German language). Berlin, New York: de Gruyter.

König W (2001) dtv-Atlas Deutsche Sprache. GmbH: Deutscher Taschenbuck Verlag. Lakoff R (1973) "Language and Woman's Place". Language in Society 2(1/Apr.): 45-80.

Mallory JP (1996) In Search of Indo-Europeans. London: Thames and Hudson.

Manley L (1980) Convention, 1500-1700. Cambridge, MA: Harvard University Press.

Marryat F (1840) Diary in America. Philadelphia: Collins.

O’Rell M (1891) A Frenchman in America. New York: Cassel.

Sapir E (1985) Selected Writings in Language, Culture, and Personality. Berkley, Los Angeles: University of California Press.

Simpson J, Weiner T (eds.) (1994) The Compact Oxford English Dictionary. Oxford: Clarendon Press.

Trollope F (1832) Domestic Manners of the Americans. Whittaker: Treacher \& Co.

Whorf BL (1967) Language, Thought, and Reality. Selected writings. The MIT Press.

Wolfram W (1998) Natalie Schilling-Estes, American English. Oxford: Blackwell Publishers. 